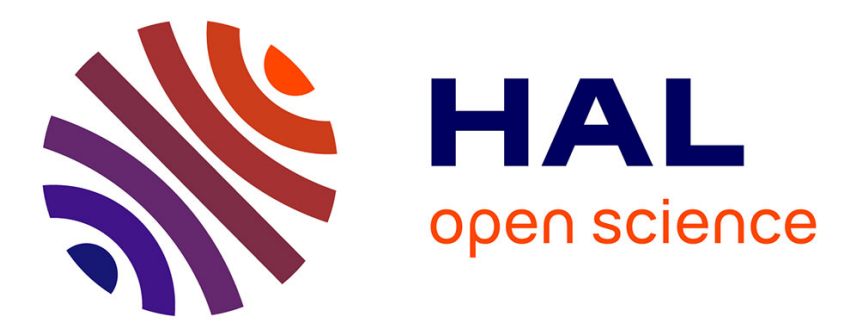

\title{
Influence of conidial traits and leaf structure on attachment success of aquatic hyphomycetes on leaf litter
}

\author{
Christian K. Dang, Mark O. Gessner, Eric Chauvet
}

\section{To cite this version:}

Christian K. Dang, Mark O. Gessner, Eric Chauvet. Influence of conidial traits and leaf structure on attachment success of aquatic hyphomycetes on leaf litter. Mycologia, 2007, 99 (1), pp.24-32. 10.3852/mycologia.99.1.24 . hal-01302323

\section{HAL Id: hal-01302323 \\ https://hal.science/hal-01302323}

Submitted on 14 Apr 2016

HAL is a multi-disciplinary open access archive for the deposit and dissemination of scientific research documents, whether they are published or not. The documents may come from teaching and research institutions in France or abroad, or from public or private research centers.
L'archive ouverte pluridisciplinaire HAL, est destinée au dépôt et à la diffusion de documents scientifiques de niveau recherche, publiés ou non, émanant des établissements d'enseignement et de recherche français ou étrangers, des laboratoires publics ou privés. 


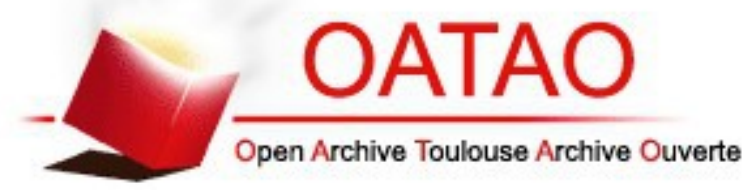

\section{Open Archive TOULOUSE Archive Ouverte (OATAO)}

OATAO is an open access repository that collects the work of Toulouse researchers and makes it freely available over the web where possible.

This is an author-deposited version published in : http://oatao.univ-toulouse.fr/ Eprints ID : 9635

To link to this article : DOI :10.3852/mycologia.99.1.24

URL : http://dx.doi.org/10.3852/mycologia.99.1.24

To cite this version : Dang, Christian $K$. and Gessner, Mark O. and Chauvet, Eric Influence of conidial traits and leaf structure on attachment success of aquatic hyphomycetes on leaf litter. (2007) Mycologia, vol. 99 ( $\mathrm{n}^{\circ}$ 1). pp. 24-32. ISSN 0027-5514

Any correspondance concerning this service should be sent to the repository administrator: staff-oatao@,listes-diff.inp-toulouse.fr 


\section{Influence of conidial traits and leaf structure on attachment success of aquatic hyphomycetes on leaf litter}

\author{
Christian K. Dang ${ }^{1}$ \\ Laboratoire Dynamique de la Biodiversité, UMR 5172 \\ CNRS-UPS, 29 rue Jeanne Marvig, 31055 Toulouse \\ Cedex, France \\ Mark O. Gessner \\ Department of Aquatic Ecology, Eawag: Swiss Federal \\ Institute of Aquatic Science and Technology, and \\ Institute of Integrative Biology (IBZ), ETH Zurich, \\ 6047 Kastanienbaum, Switzerland \\ Eric Chauvet \\ Laboratoire Dynamique de la Biodiversité, UMR 5172 \\ CNRS-UPS, 29 rue Jeanne Marvig, 31055 Toulouse \\ Cedex, France
}

\begin{abstract}
Attachment of conidia on leaves is a critical first step in the life cycle of aquatic hyphomycetes in streams. In a first series of microcosm experiments, attachment success of three common aquatic hyphomycete species differing in conidial shape (compact, filiform and tetraradiate) was determined on two leaf species, black alder and downy oak. Fungal species identity and leaf surface structure significantly affected conidial attachment after $24 \mathrm{~h}$. The lower sides of oak leaves with extensive tufts trapped 2.4-8.8 more conidia than the upper sides of oak leaves and both sides of alder leaves. In a second experiment with seven fungal species, attachment success of two species with tetraradiate conidia was much greater than that of two other tetraradiate and three compact conidia, which all had similar attachment success. The species with the largest spores was also the most successful, but this pattern was not consistent across the size range of tested conidia. These results highlight the importance of leaf surface structure, possibly conidial shape and size and additional properties of aquatic hyphomycete conidia in determining attachment success on leaves and they point to the potential role of these factors in structuring fungal communities on decomposing leaves in streams.
\end{abstract}

Key words: aquatic hyphomycetes, attachment, conidial shape, decomposition, leaf litter, stream

${ }^{1}$ Corresponding author. Current address: Department of Zoology, Ecology and Plant Sciences, University College Cork, Cork, Ireland. E-mail: C.Dang@ucc.ie

\section{INTRODUCTION}

Aquatic hyphomycetes are important drivers of leaf litter decomposition in streams, a fundamental ecosystem process in forested catchments (Bärlocher and Kendrick 1974, Suberkropp and Klug 1976, Gessner and Chauvet 1994, Hieber and Gessner 2002, Pascoal and Cássio 2004). Colonization of leaves and other substrates by aquatic hyphomycetes may occur through three pathways: by direct contact as a result of hyphal outgrowth from a colonized leaf touching another leaf or piece of wood; at a distance by either detached hyphal fragments (Park 1974, Knudsen and Stack 1991) or asexual spores called conidia (Read et al 1992) that land on a leaf surface. The last mechanism appears to be the predominant one to colonize distant leaf patches (Sridhar and Bärlocher 1997).

Once settled on a substrate, conidia of aquatic hyphomycetes germinate within hours, or less (Read et al 1992; Au et al 1996), by developing one or more germ tubes that generally form appresoria on the substratum (Read et al 1992). These structures ensure a solid adherence to the colonized surface (Webster and Davey 1984) and subsequently permit the fungus to penetrate the plant tissue (Hatzipapas et al 2002). At the beginning of colonization, hyphal extension in leaf tissue can be rapid, with growth rates measured in leaf litter of up to $0.72 \mathrm{~d}^{-1}$ (Suberkropp and Weyers 1996, Gessner and Chauvet 1997, Pascoal and Cássio 2004). In contrast to most other fungi, aquatic hyphomycetes typically start to produce and release conidia soon after initial colonization of a new substrate, and the high sporulation activity of up to 7000 conidia produced per mg leaf dry mass per day (Bärlocher 1982, Suberkropp 1991, Gessner and Chauvet 1994, Gulis and Suberkropp 2003, Pascoal et al 2005) results in conidial concentrations in headwater streams that can reach several thousands per liter during autumn leaf fall (Webster and Descals 1981, Bärlocher 1992). Conidia of aquatic hyphomycetes released into flowing water may be carried from a few hundred meters to a few kilometers (Thomas et al 1990) and can maintain their ability to germinate for several days (Iqbal and Webster 1973, Sridhar and Bärlocher 1994). However, unlike conidia of many other fungi, those of aquatic hyphomycetes are not designed as resting stages, and their delicate structure suggests that prolonged maintenance of viability is limited (Sridhar and Bärlocher 1994). Furthermore 
there is evidence that early establishment on a freshly fallen leaf confers early colonizers a competitive advantage over fungi arriving at a later stage (Bärlocher and Schweizer 1983, Suberkropp and Chauvet 1995). Thus efficient attachment to a suitable fresh substratum is a most critical point in the life cycle of these fungi.

In contrast to most terrestrial fungi, aquatic hyphomycetes show a variety of characteristic conidial shapes, which range from compact to filiform to branched. Tetraradiate shape as the dominant branched type and filiform shape are the most common, with experimental evidence suggesting that more complex shapes result from adaptation to turbulent aquatic environments (Webster 1959, Webster and Davey 1984, Webster 1987). Accordingly conidia with tetraradiate shape are trapped on surfaces most efficiently, making simultaneous contact with the tips of three of their branches. Filiform conidia are often sigmoid (i.e. twisted in three dimensions), which ensures two contact points, whereas compact forms only have one and consequently should be least efficient at attaching to surfaces, especially in turbulent conditions. Differences in the surface roughness of leaves, both among species and between the upper and lower leaf side, might further influence attachment success. This idea led Bärlocher (1992) to suggest that some observed difference in community structure of aquatic hyphomycetes on different leaf species in the same stream (Thomas et al 1992, Gulis 2001) might be caused partly by varying success among species during the initial conidial settlement and germination phases.

The aim of this study was to determine the variability in attachment success on natural leaf surfaces among the three most common types of conidia (branched/tetraradiate, filiform/sigmoid and compact) belonging to widespread aquatic hyphomycete species. To this end we first compared attachment success on two types of leaves of three aquatic hyphomycete species, each exhibiting one of the three basic conidial shapes. We used black alder (Alnus glutinosa [L.] Gaertn.) and downy oak (Quercus humilis Miller) to test whether leaf surface structure influences conidial attachment by comparing attachment success on the upper (adaxial) and lower (abaxial) sides of leaves. Leaf blades of both species have smooth upper and rougher lower sides, the latter resulting from protruding veins and more or less numerous and extensive tufts. Given the greater importance of tufts on oak leaves, we expected roughness to be greatest on the lower side of oak leaves and lowest on upper leaf surfaces. Thus we hypothesized that (i) differences in surface structure between leaf sides influence conidial attach- ment; (ii) simple compact conidia are less influenced by surface structures than filiform unbranched and tetraradiate conidia, which are more likely to get trapped by tufts; and (iii) filiform and tetraradiate conidia attach more efficiently than conidia with simple compact shape, even on smooth surfaces. In a second experiment we tested with a greater number of fungal species whether tetraradiate conidia are more efficient at attaching to leaves than compact conidia.

\section{MATERIALS AND METHODS}

Production of conidia.-All fungal strains were obtained from single conidia isolated from river foam and grown on 2\% malt agar (Merck 1.11929). Tetrachaetum elegans Ingold (Te, CERR28-1457), Flagellospora curvula Ingold (Fc, CERR81-150) and Heliscus lugdunensis Saccardo \& Thérry ( $\mathrm{Hl}$, CERR28-1453) were chosen for the first experiment as representatives of tetraradiate, filiform and compact conidial shapes, respectively (FIG. 1). Five additional species were used in the second experiment. These were Alatospora acuminata Ingold (Aa, CERR28-1464), Articulospora tetracladia (At, CERR28-1458) and Tetracladium marchalianum de Wild. (Tm, CERR28-1454) with tetraradiate conidia, and Goniopila monticola (Dyko) Marvanová \& Descals ( Gm, CERR28-1455) and Tumularia aquatica (Ingold) Descals \& Marvanová (Ta, CERR28-1461) with compact conidia (FIG. 1).

Sporulation of aquatic hyphomycetes was induced by soaking strips of 7-10 d old colonies on $2 \%$ malt agar in microcosms designed for studying fungal leaf decomposition in streams (see Suberkropp 1991 for details). Forty mL of nutrient solution containing per liter $100 \mathrm{mg} \mathrm{CaCl}_{2} \cdot 2$ $\mathrm{H}_{2} \mathrm{O}, 10 \mathrm{mg} \mathrm{MgSO}_{4} \cdot 2 \mathrm{H}_{2} \mathrm{O}, 0.5 \mathrm{~g}$ 3-morpholinopropane-

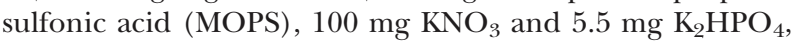
with $\mathrm{pH}$ adjusted to 7.0 were added to each microcosm (Dang et al 2005). Microcosms and nutrient solutions of cultures were autoclaved before inoculation. Air flow through microcosms was adjusted to $80 \mathrm{~mL} \min ^{-1}$ during experiments and temperature was maintained at $15 \mathrm{C}$. Conidia produced after 24-48 h were used in experiments.

Experimental design. - Leaf disks (1 cm diam) were cut from freshly fallen alder and oak leaves with a cork borer, autoclaved, air dried and stored. Although autoclaving and drying of leaves may affect surface structure of leaves, we assumed such changes would be small and that any effects on attachment would vary little across fungal species. Six disks of each leaf species were introduced into each of three replicate microcosms (Suberkropp 1991) and incubated with aeration for $24 \mathrm{~h}$ before adding a conidial suspension of a single species. In a first series of experiments about 10000 conidia for F. curvula and H. lugdunensis or 2000 for the much larger $T$. elegans were used. Number of conidia in the inoculum was verified by staining and counting the conidia of three additional inocula on membrane filters (Gessner et al 2003). The same protocol 


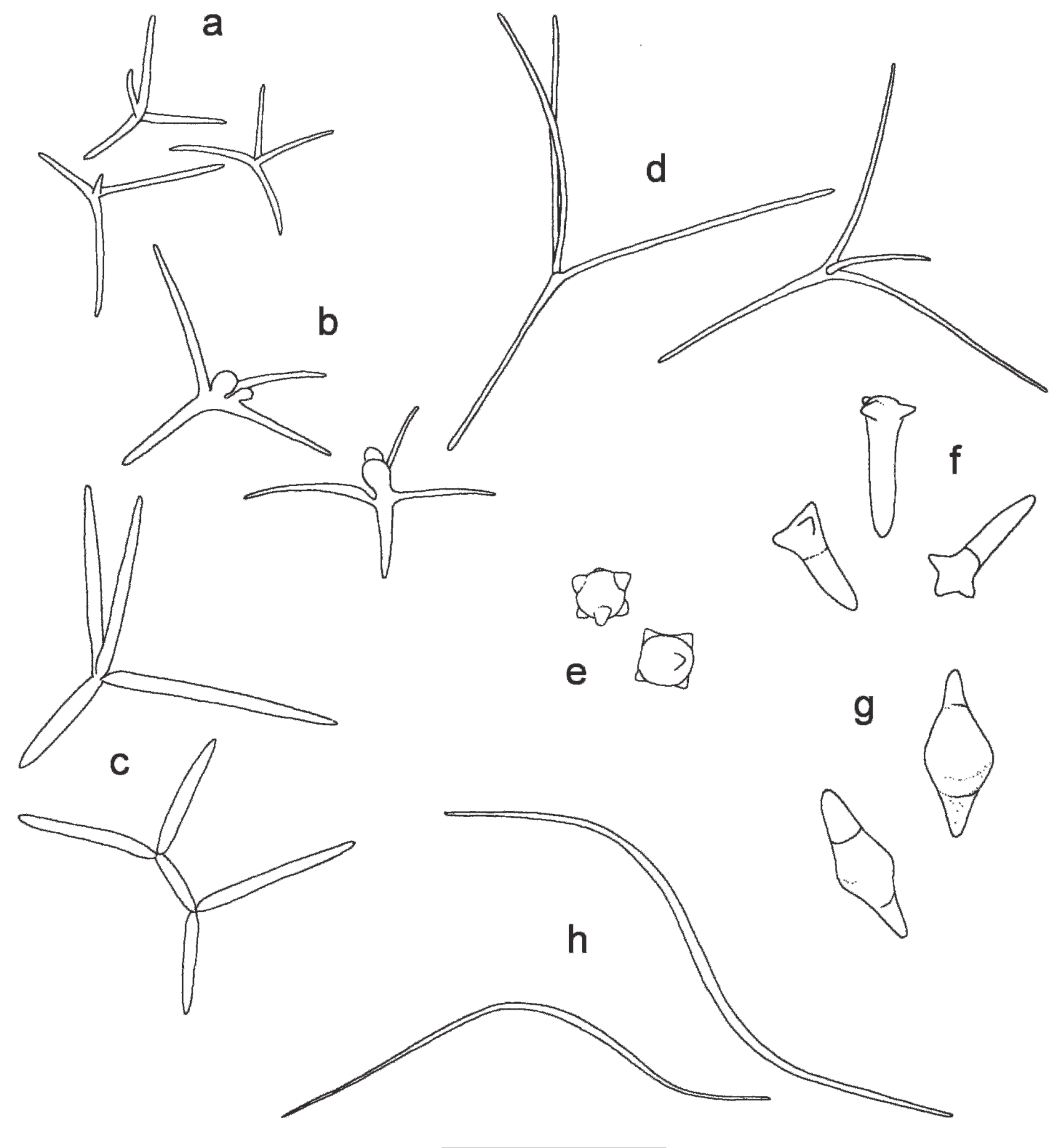

FIG. 1. Conidia of Alatospora acuminata. a. Tetracladium marchalianum. b. Articulospora tetracladia. c. Tetrachaetum elegans. d. Goniopila monticola. e. Heliscus lugdunensis. f. Tumularia aquatica. g. Flagellospora curvula. $\mathrm{h} . \mathrm{Bar}=50 \mu \mathrm{m}$ $(\mathrm{a}-\mathrm{c}, \mathrm{e}-\mathrm{h})$ or $100 \mu \mathrm{m}(\mathrm{d})$. After Chauvet (1990).

was followed in the second experiment, except that microcosms were inoculated simultaneously with all seven species and that each of three replicate microcosms received 12 alder leaf disks and ca. 17000 conidia of each fungal species.
Experimental procedures.-After $24 \mathrm{~h}$ incubation the microcosms were drained and the solution filtered through membrane filters $(5.0 \mathrm{~mm}$ pore size, nitrocellulose, Whatman International Ltd., Maidstone, UK). Conidia on filters were stained with trypan blue $(0.1 \%)$ in lactic acid $(60 \%)$ 
and counted (see below). Leaf disks were removed carefully from microcosms with tweezers, stained with trypan blue and placed between a slide and cover slip. In the first series of experiments conidial attachment was checked by scanning the entire surface area of both sides of all leaf disks under a Zeiss Axioplan microscope at $160 \times$ to obtain an exhaustive account of all settled conidia. Conidia first were counted on the leaf side facing the cover slip, then the slide was turned upside down and conidia counted on the side facing the slide. In the second experiment to assess success of the two extreme conidial shapes, a total of three lower and three upper sides of the 12 leaf disks per microcosm were scanned.

Data analyses.-Attachment success was assessed as the percentage of conidia attached to each side of all leaf disks from a given microcosm. Because a conidium can settle only on one side of a given disk in a microcosm, conidial attachment events are not statistically independent and analyses with parametric statistical tests are inappropriate (Sridhar et al 2001). However conidial attachment events are independent among replicate microcosms, which were treated as blocks in analyses. The influence of leaf surface structure (i.e. leaf species and side) and fungal species on conidial attachment success was analysed by two-way randomized ANOVA (cf. Bärlocher 2005) after arcsinesquare root transformation of data; the routine was written in Matlab 6.5 for PC. To maintain independence among blocks, permutations were restricted to within blocks (i.e. microcosms) by shuffling all data (Sridhar et al 2001). After each shuffling (permutation), F-statistics were calculated as in a normal two-way ANOVA. Based on 10000 permutations significance was inferred from the number of F-values as extreme as, or more extreme than, the initial F-value (i.e. $\mathrm{F}_{0}$ obtained from the empirically observed data). When the test was significant, differences between pairs were tested by Tukey's HSD test with the same permutation method. In the second experiment, the influence of species on attachment success was analyzed by one-way randomized ANOVA on arcsine-square root transformed data followed by Tukey's HSD test, using similar procedures as in Experiment 1. Finally Spearman's correlation was calculated between effective volume of conidia and attachment success to assess whether conidial size could have influenced attachment success in the second experiment. Effective volume of conidia was approximated by a sphere in the case of tetraradiate conidia and $G$. monticola, a cone for $H$. lugdunensis and a double cone for T. aquatica (FIG. 1).

\section{RESULTS}

Microscopic observations revealed that all conidia settled on the leaves had germinated. Leaf side had a strong effect on conidial attachment $(\mathrm{F}=68.5, P<$ $0.0001)$, with the lower side of oak trapping significantly more conidia of $T$. elegans and $F$. curvula than both the upper side of oak and either side of alder leaves (FIG. 2, TABLE I). Microscopic observations showed that when a branch of a tetraradiate conidium
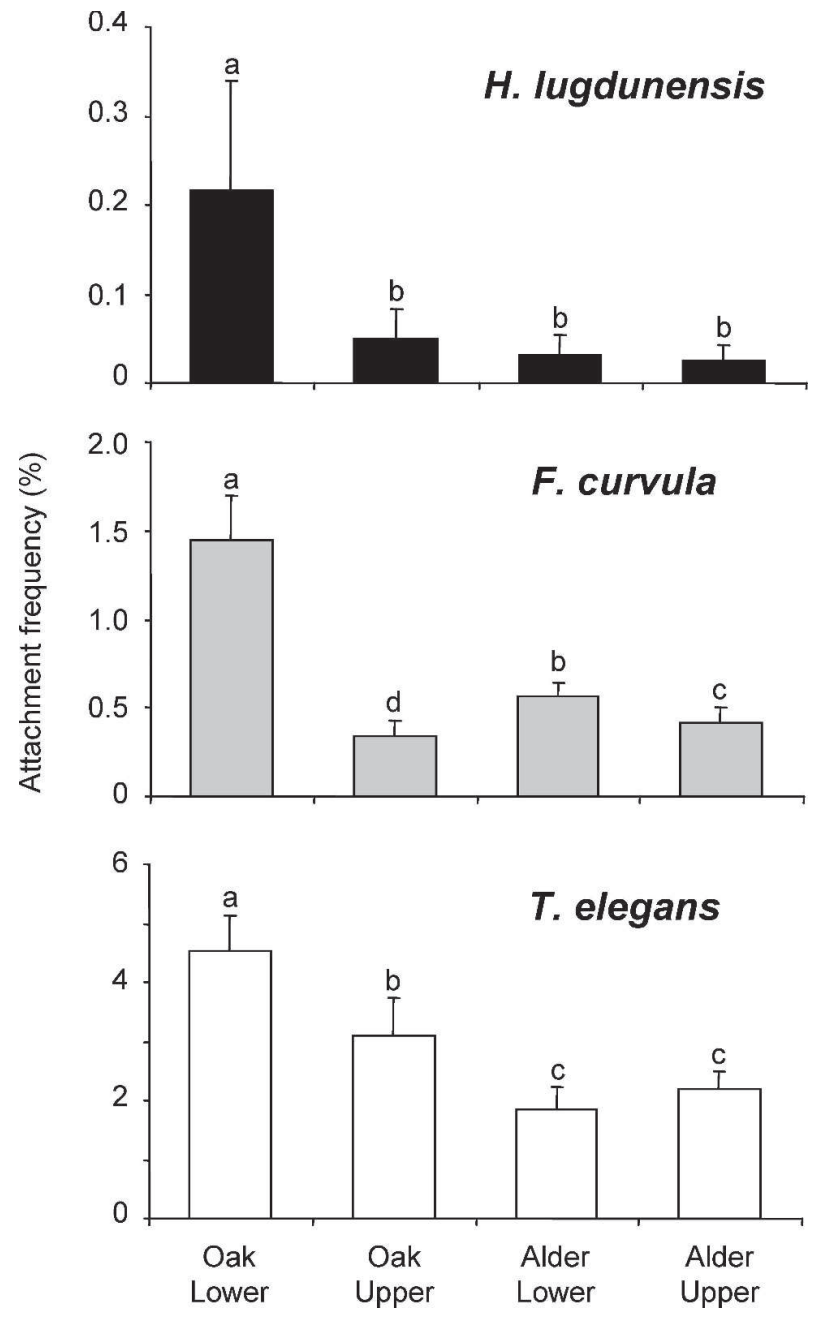

FIG. 2. Attachment success of three aquatic hyphomycete species on leaves expressed as frequency of inoculated conidia settled on one side of one leaf disk in microcosms (mean $\pm 1 \mathrm{SE}, \mathrm{n}=18$ ). Alder and oak leaves as well as upper and lower sides of leaves were considered separately. Black, gray and white bars indicate species with compact, filiform and tetraradiate conidia respectively. Leaf species/ side combinations that were significantly different according to randomized Tukey's test are indicated by lowercase letters.

or a filiform conidium encountered a hair on the lower side of an oak leaf (FIG. 3) the conidium got entangled and remained trapped and developed one or more germ tubes that often reached the leaf surface. Even the compact conidia of H. lugdunensis were significantly more abundant on the lower side of oak leaves (FIG. 2).

Conidial attachment varied greatly among the three fungal species with a total attachment frequency (all conidia attached to the two leaf species combined) of $70 \pm 12 \%$ (mean $\pm 1 \mathrm{SD}$ ) for the large 
TABLE I. Results of two-way randomized ANOVA testing for effects of fungal species and leaf side on attachment success by aquatic hyphomycete conidia

\begin{tabular}{lcrlrc}
\hline \hline \multicolumn{1}{c}{ Factor } & SS & df & \multicolumn{1}{c}{ MS } & F & $P$ \\
\hline Fungal species & 0.77 & 2 & 0.39 & 882.5 & $<0.0001$ \\
Leaf side & 0.090 & 3 & 0.030 & 68.5 & $<0.0001$ \\
$\begin{array}{l}\text { Fungal species } \\
\quad \times \text { leaf side }\end{array}$ & 0.026 & 6 & 0.0043 & 9.8 & $<0.0001$ \\
Error & 0.089 & 204 & 0.00044 & & \\
\hline
\end{tabular}

tetraradiate conidia of T. elegans, $16.6 \pm 5.4 \%$ for the filiform conidia of $F$. curvula and $1.9 \pm 2.4 \%$ for the compact conidia of $H$. lugdunensis. In contrast to the other species $H$. lugdunensis never developed appresoria on leaf surfaces. Few conidia of $T$. elegans remained suspended after $24 \mathrm{~h}(2.7 \pm 1.9 \%)$, whereas about half $(53 \pm 19 \%)$ of the $H$. lugdunensis conidia remained in suspension. Suspended conidia of $F$. curvula were not counted because they were not clearly distinguishable from hyphal fragments once they had germinated. Indeed after $24 \mathrm{~h}$ conidial suspensions of all species contained a high number of hyphal fragments, although inocula were almost free of hyphae. Inspection of the glass walls of microcosms under a dissecting microscope revealed a substantial number of attached conidia; however, because of the shape of microcosm, it was impossible to obtain reliable counts of these conidia.

Attachment success of the seven fungal species used in Experiment 2 is shown (FIG. 4). Species identity

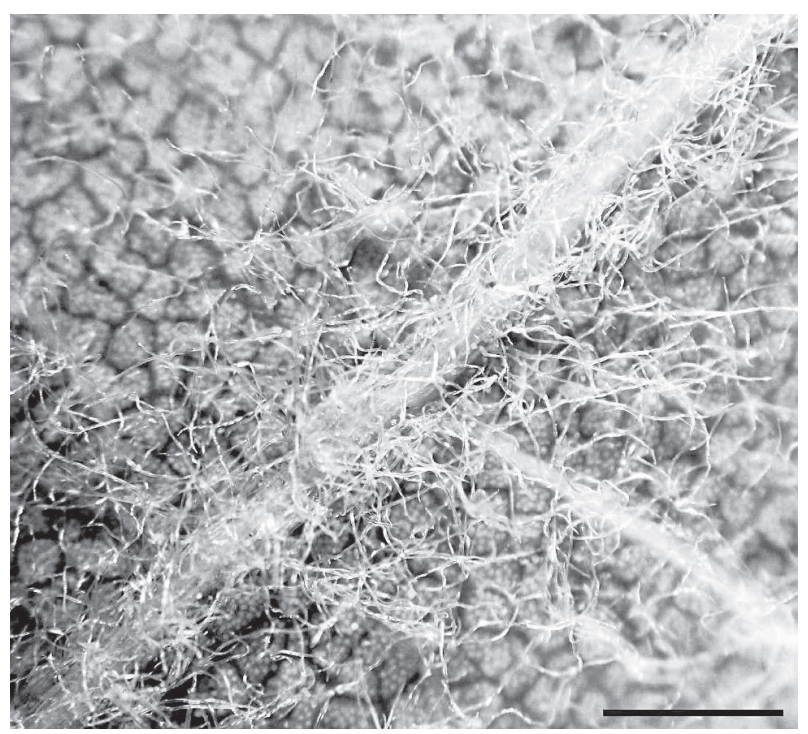

FIG. 3. View of the lower side of a downy oak leaf showing tuft that might be instrumental in increasing attachment success of aquatic hyphomycete conidia on leaf surfaces. Bar $=1 \mathrm{~mm}$.

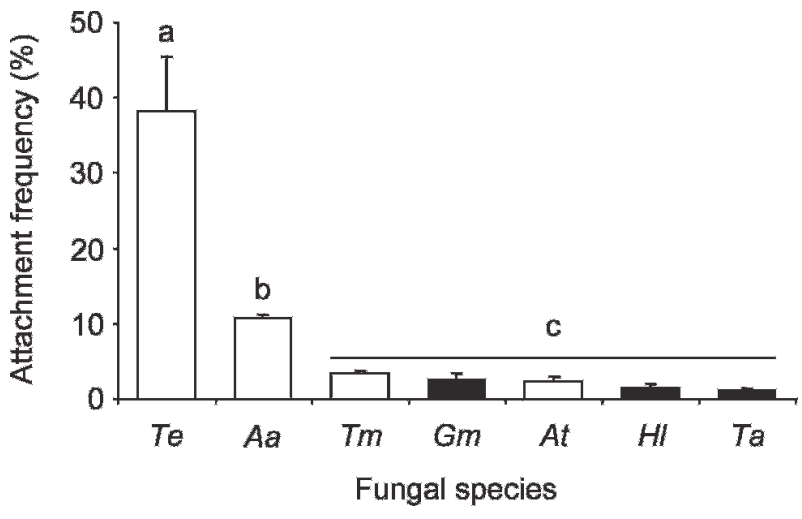

FIG. 4. Attachment success of seven aquatic hyphomycete species on leaves expressed as the frequency of inoculated conidia settled on leaf disks in microcosms (mean $\pm 1 \mathrm{SE}, n=3$ ). Tetrachaetum elegans (Te), Alatospora acuminata (Aa), Tetracladium marchalianum (Tm), Goniopila monticola $(\mathrm{Gm})$, Articulospora tetracladia (At), Heliscus lugdunensis $(\mathrm{Hl})$ and Tumularia aquatica $(\mathrm{Ta})$. White bars indicate species with tetraradiate conidia, gray bars species with compact conidia. Species significantly different according to a randomized Tukey's test are indicated by lowercase letters.

had a highly significant effect $(\mathrm{F}=68.3, P<0.0001)$, confirming results from Experiment 1 that large differences in attachment success exist among individual fungal species. There were also significant differences between fungal shapes, with two tetraradiate species exhibiting the highest attachment frequencies (FIG. 4). In accordance with results of Experiment $1 T$. elegans conidia were much more successful in attaching to leaves than all other species $(38 \pm 13 \%)$ (FIG. 4). The second tetraradiate species (A. acuminata) had significantly lower attachment frequencies of $10.8 \pm 0.8 \%$, and attachment success of the five other species (tetradiate $T$. marchalianum $3.4 \pm 0.7 \%$ and A. tetracladia $2.6 \pm 0.4 \%$, and compact G. monticola $2.7 \pm 1.1 \%$, H. lugdunensis 1.3 $\pm 1.1 \%$ and $T$. aquatica $1.1 \pm 0.6 \%$ ) were similar. As a result multiple comparisons by Tukey's test following randomized ANOVA (TABLE II) differentiated three groups (FIG. 4).

An apparent relationship between size (i.e. effective volume) of conidia and attachment success (FIGS. 1 and 4) was driven strongly by a single species with large conidia and high attachment success ( $T$. elegans) at one extreme and a cluster of smaller species at the other end. As a result effective volume and attachment success were not significantly correlated when assessed as Spearman's rank correlation $\left(r_{\mathrm{s}}=0.54, P=0.22\right)$. Further, when this large species was removed from the analysis, the previously apparent relationship disappeared altogether $\left(r_{\mathrm{s}}=\right.$ 
TABLE II. Summary of pairwise comparisons ( $\mathrm{P}$ values) made by randomized Tukey's test of aquatic hyphomycete attachment success on leaves. Alatospora acuminata (Aa), Articulospora tetracladia (At), Goniopila monticola (Gm), Tetracladium marchalianum (Tm), Heliscus lugdunensis (Hl), Tumularia aquatica (Ta) and Tetrachaetum elegans (Te)

\begin{tabular}{lcccccc}
\hline \hline & $A a$ & At & Gm & Tm & $H l$ & $T a$ \\
\hline At & 0.005 & & & & \\
$G m$ & 0.004 & 0.97 & & & \\
$T m$ & 0.016 & 0.37 & 0.36 & & \\
$H l$ & $<0.001$ & 0.35 & 0.38 & 0.21 & \\
$T a$ & $<0.001$ & 0.29 & 0.32 & 0.17 & 0.90 \\
$T e$ & $<0.0001<0.0001<0.0001<0.0001<0.0001<0.0001$ \\
\hline
\end{tabular}

0.26, $P=0.62)$, although effective volumes of the remaining species still differed by a factor of 17 .

\section{DISCUSSION}

To our knowledge this study is the first to estimate the attachment success of aquatic hyphomycete conidia on leaf litter. Webster (1959) found that conidial shape significantly influences attachment on collodion-coated objects submerged in flowing water. The present results lend partial support to Webster's (1959) conclusion that tetraradiate conidia confer a competitive advantage because conidia of two tetraradiate species attached to leaf surface more efficiently than compact forms. However species with tetraradiate conidia exhibited a large range of attachment frequencies, with no statistically detectable difference between the two least efficient tetraradiate and three compact conidia. This suggests that factors other than shape are also important in determining attachment success of aquatic hyphomycetes on leaves.

Higher attachment rates of tetraradiate conidia have been attributed to the greater number of contact points that settling conidia make with the substratum. The rationale is that the tetraradiate shape ensures simultaneous contact at three points and thus results in better adherence on surfaces than the single contact point of compact conidia and two made by sigmoid conidia (Webster and Davey 1984, Read et al 1991, Bärlocher 1992). Why then did conidial attachment success vary markedly among species with conidia of similar shape? Cox (1983) suggested that effective size is important because size is proportional to the probability that a spore hits a target object. This hypothesis is consistent with the high attachment success of $T$. elegans, the species in our experiments with by far the largest conidia. However $A$. acuminata, the second most successful species, has conidia of intermediate size only (FIG. 1). Thus, although it cannot be ruled out that conidial size plays a role in determining attachment success, additional factors appear to be influential as well. One additional factor, unrelated to conidial shape or size, might be length of the germ tube that is formed before an appressorium is developed because quick development of appresoria at the end of germ tubes ensures firm attachment of newly settled conidia colonizing leaf surfaces (Webster and Davey 1984, Read et al 1991; $\mathrm{Au}$ et al 1996). In contrast to G. monticola and the tetraradiate species, which produced short germ tubes before forming appresoria, conidia of $T$. aquatica usually developed long tubes before an appressorium was formed. This delay in appressorium formation might explain the particularly low attachment frequency of $T$. aquatica compared to all other species tested.

H. lugdunensis never developed appresoria on leaves in the present study, nor have these structures been observed on either glass surfaces or membrane filters in a previous investigation (Read et al 1991). Lack of an effective holdfast before hyphae penetrate the plant tissue may result in high vulnerability of settled conidia to turbulence, which could wash away conidia that are only loosely attached, consistent with our observation that more than half of the $H$. lugdunensis conidia added to microcosms remained in suspension after $24 \mathrm{~h}$. The notable absence of appressorium formation in $H$. lugdunensis might be related to the regular occurrence of this hyphomycete in terrestrial habitats (Sridhar and Bärlocher 1993), from where it first was described (Saccardo 1880) and where firm attachment is less critical than in flowing water. Furthermore H. lugdunensis, like T. aquatica, has been reported from submerged wood (Shearer 1992), a much less ephemeral resource than leaves, suggesting that attachment success might play a less critical role in the life cycle of these species compared to other aquatic hyphomycetes. Finally the weaker ability of both $H$. lugdunensis and $T$. aquatica to attach to leaf surfaces might be related to the presence of glycogen as dominant carbon storage product (Ingold 1975), which has been suggested to reduce germination potential (Read et al 1992).

In addition to conidial shape and other traits of aquatic hyphomycetes, attachment success of conidia was affected significantly by leaf surface structure. Both filiform and tetraradiate conidia were trapped most efficiently by tufts on the lower side of oak leaves (FIG. 3), which functioned like a comb and thus increased settlement rates. We had expected that compact conidia would be less responsive to differences in leaf surface structure. However compact conidia, such as those of $H$. lugdunensis, also were 
trapped preferentially by tufts on the lower side of oak leaves (FIG. 3), an observation also made with conidia of G. monticola (data not shown). Microscopic observation suggested that this could be due to the fact that conidia are no longer compact once they have germinated and therefore might get entrapped with their extended germ tubes in a similar way as filiform conidia. Because attachment success was evaluated only $24 \mathrm{~h}$ after inoculation of microcosms it is not clear from the present results whether conidia germinated before or after entrapment. However, if they germinated in suspension, it would support Cox's (1983) suggestion that alteration of conidial shape by germination might render attachment to leaf surfaces more efficient.

Another critical factor to consider in assessing attachment success of aquatic hyphomycete conidia is thickness of the boundary layer on leaf surfaces. Given the small size even of large conidia (FIG. 1) conidia simply might get trapped in this boundary layer where flow is greatly reduced (Statzner et al 1988). Leaf surface structures such as tufts are likely to increase thickness of the boundary layer and thus increase chances of conidia of all sizes and shapes to be trapped, irrespective of a comb effect of tufts.

The weak attachment of conidia in the present experiments is likely to be related to the high turbulence prevailing in stream microcosms, which are aerated from underneath (Suberkropp 1991). However such turbulent conditions typically are encountered in running water, even though specific hydraulic characteristics may differ between microcosms and the field. Attachment of aquatic hyphomycetes is a critical stage in the colonization of fresh substrata in flowing water. Indeed aquatic hyphomycetes in streams are likely to experience large losses of conidia that never germinate on a suitable substratum. This is because conidia are constantly transported downstream with the unidirectional flow of water and have a tendency to attach to any solid substratum they encounter, such as a leaf or piece of wood, but also to mineral surfaces (Read et al 1992). Additional losses during transport occur through consumption by filter-feeding invertebrates (Bärlocher and Brendelberger 2004). In view of the rapid colonization of freshly fallen leaves in streams by aquatic hyphomycetes, it appears that the enormous number of conidia released by these fungi (Bärlocher 1992) is sufficient to compensate for these losses and inefficiencies in attaching to suitable substrates.

In conclusion the results of this study show that species identity clearly affects attachment success of aquatic hyphomycetes on leaf surfaces. Shape of conidia may partially determine success, whereas the importance of size is not clear, suggesting that other characteristics of conidia are also influential. In addition to conidial traits leaf surface structure plays an important role in determining attachment success, particularly the presence of tufts in which conidia can get entrapped and which are likely to increase thickness of the boundary layer at the leaf-water interface. Given that settling of conidia on, and attachment to, leaf surfaces is a critical step in the life cycle of aquatic hyphomycetes, marked differences in attachment success might have implications for structuring aquatic hyphomycete communities on decomposing leaves in streams. For example $T$. elegans was highly efficient in the present study at attaching to alder leaves, consistent with the frequent record of this fungus as a dominant species during early stages of leaf colonization in natural streams (e.g. Chamier and Dixon 1982, Bärlocher 1991a, Gessner et al 1993). However traits of aquatic hyphomycetes, such as efficiency of resource capture, growth rate, competitive ability (Bärlocher 1991b, Yuen et al 1999, Treton et al 2004), and resistance to predation (Arsuffi and Suberkropp 1989), are likely to be additional determinants that shape aquatic hyphomycete community structure. Considerably more information clearly is needed to elucidate the factors governing establishment of aquatic hyphomycete communities on leaf litter in streams.

\section{ACKNOWLEDGMENTS}

We thank B. Malmqvist, M. Gardes, M.A.S. Graça and two anonymous reviewers whose comments led to significant improvements of the manuscript. This study was supported through the RivFunction project financed by the EU Commission (EVK1-CT-2001-00088) and the Swiss State Secretariat for Education and Research (SBF No. 01.0087).

\section{LITERATURE CITED}

Arsuffi TL, Suberkropp K. 1989. Selective feeding by shredders on leaf-colonizing stream fungi: comparison of macroinvertebrate taxa. Oecologia 79:30-37.

Au DWT, Jones EBJ, Moss ST, Hodgkiss IJ. 1996. The role of mucilage in the attachment of conidia, germ tubes, and appresoria in the saprobic aquatic hyphomycetes Lemonniera aquatica and Mycocentrospora filiformis. Can J Bot 74:1789-1800.

Bärlocher F. 1982. On the ecology of Ingoldian fungi. BioScience 32:581-585.

. 1991a. Fungal colonization of fresh and dried leaves in the River Teign (Devon, England). Nov Hedwig 52: 349-357.

—. 1991b. Intraspecific hyphal interactions among aquatic hyphomycetes. Mycologia 83:82-88.

. 1992. Community organization. In: Bärlocher F, ed. The ecology of aquatic hyphomycetes. New York: Springer-Verlag. p 38-76. 
2005. A primer for statistical analysis. In: Graça MAS, Bärlocher F, Gessner MO, eds. Methods to study litter decomposition. Berlin/New York: Springer-Verlag. 329 p.

—_ Brendelberger H. 2004. Clearance of aquatic hyphomycete spores by a benthic suspension feeder. Limnol Oceanogr 49:2292-2296.

—, Kendrick B. 1974. Dynamics of the fungal population on leaves in a stream. J Ecol 62:761-789.

—, Schweizer M. 1983. Effects of leaf size and decay rate on colonization by aquatic hyphomycetes. Oikos 41:205-210.

Chamier AC, Dixon PA. 1982. Pectinases in leaf degradation by aquatic hyphomycetes I: the field study. Oecologia 52:109-115.

Chauvet E. 1990. Hyphomycètes aquatiques du sud-ouest de la France. Gaussenia 6:3-31.

Cox PA. 1983. Search theory, random motion and the convergent evolution of pollen and spore morphology in aquatic plants. Am Nat 121:9-31.

Dang CK, Chauvet E, Gessner MO. 2005. Magnitude and variability of process rates in fungal diversity-litter decomposition relationships. Ecol Lett 8:1129-1137.

Gessner MO, Bärlocher F, Chauvet E. 2003. Qualitative and quantitative analyses of aquatic hyphomycetes in streams. In: Tsui CKM, Hyde KD, eds. Freshwater Mycology Fungal. Hong Kong: Diversity Press. p 127157.

— Chauvet E. 1994. Importance of stream microfungi in controlling breakdown rates of leaf litter. Ecology 75 : 1807-1817.

- -1997 . Growth and production of aquatic hyphomycetes in decomposing leaf litter. Limnol Oceanogr 42:496-505.

—, Thomas M, Jean-Louis A-M, Chauvet E. 1993. Stable successional patterns of aquatic hyphomycetes on leaves decaying in a summer cool stream. Mycol Res 97:163-172.

Gulis VI. 2001. Are there any substrate preferences in aquatic hyphomycetes? Mycol Res 105:1088-1093.

- Suberkropp K. 2003. Leaf litter decomposition and microbial activity in nutrient-enriched and unaltered reaches of a headwater stream. Freshw Biol 48:123-134.

Hatzipapas P, Kalosaka K, Dara A, Christias C. 2002. Spore germination and appressorium formation in the entomopathogenic Alternaria alternata. Mycol Res 106:1349-1359.

Hieber M, Gessner MO. 2002. Contribution of stream detrivores, fungi, and bacteria to leaf breakdown based on biomass estimates. Ecology 83:1026-1038.

Ingold T. 1975. An illustrated guide to aquatic and waterborne hyphomycetes. Freshw Biol Assoc Sci Pub, $96 \mathrm{p}$.

Iqbal SH, Webster J. 1973. The trapping of aquatic hyphomycete spores by air bubbles. Trans Br mycol Soc 60:37-48.

Knudsen GR, Stack JP. 1991. Modeling growth and dispersal of fungi in natural environments. In: Arora DK, Rai B, Mukerji KG, Knudsen G, eds. Handbook of applied mycology. New York: Marcel Dekker. p 625-645.
Park D. 1974. Accumulation of fungi by cellulose exposed in a river. Trans Br Mycol Soc 63:437-447.

Pascoal C, Cássio F. 2004. Contribution of fungi and bacteria to leaf litter decomposition in a polluted river. Appl Environ Microbiol 70:5266-5273.

— - - Marvanová L. 2005. Anthropogenic stress may affect aquatic hyphomycete diversity more than leaf decomposition in a low-order stream. Arch Hydrobiol 162:481-496.

Read SJ, Moss ST, Jones EBJ. 1991. Germination and development of attachment structures by conidia of aquatic Hyphomycetes: light microscope studies. Can J Bot 70:831-837.

1992. Attachment and germination of conidia. In: Bärlocher F, ed. The ecology of aquatic hyphomycetes. New York: Springer-Verlag. p 135-151.

Saccardo PA. 1880. Conspectus generum fungorum italiae inferiorum. Michelia 2:1-38.

Shearer CA. 1992. The role of woody debris. In: Bärlocher F, ed. The ecology of aquatic hyphomycetes. New York: Springer-Verlag. p 77-98.

Sridhar KR, Bärlocher F. 1993. Aquatic hyphomycetes on leaf-litter in and near a stream in Nova Scotia, Canada. Mycol Res 97:1530-1535.

— - 1994. Viability of aquatic hyphomycete conidia in foam. Can J Bot 72:106-110.

1997. Water chemistry and sporulation by aquatic hyphomycetes. Mycol Res 101:591-596.

, Krauss G, Bärlocher F, Raviraja NS, Wennrich R, Baumbach R, Krauss GJ. 2001. Decomposition of alder leaves in two heavy metal-polluted streams in central Germany. Aquat Microb Ecol 26:73-80.

Statzner B, Gore JA, Resh VH. 1988. Hydraulic stream ecology-observed patterns and potential applications. J N Am Benthol Soc 7:307-360.

Suberkropp K. 1991. Relationships between growth and sporulation of aquatic hyphomycetes on decomposing leaf litter. Mycol Res 95:843-850.

, Chauvet E. 1995. Regulation of leaf breakdown by fungi in streams: influences of water chemistry. Ecology 76:1433-1445.

— Klug MJ. 1976. Fungi and bacteria associated with leaves during processing in a woodland stream. Ecology 57:707-719.

— Weyers HS. 1996. Application of fungal and bacterial production methodologies to decomposing leaves in streams. Appl Environ Microbiol 62:1610-1615.

Thomas K, Chilvers GA, Norris RH. 1990. A dynamic model of fungal spora in a freshwater stream. Mycol Res 95: 184-188.

— - - -1992 . Aquatic hyphomycetes from different substrata: substrate preference and seasonal occurrence. Austr J Mar Freshw Res 43:491-509.

Treton C, Chauvet E, Charcosset JY. 2004. Competitive interaction between two aquatic hyphomycete species and increase in leaf litter breakdown. Microb Ecol 48: 439-446.

Webster J. 1959. Experiments with spores of aquatic hyphomycetes I: sedimentation and impaction on smooth surfaces. Ann Bot 23:595-611. 
1987. Convergent evolution and the functional significance of spore shape in aquatic and semi-aquatic fungi. In: Rayner ADM, Brasier CM, Moore D, eds. Evolutionary biology of the fungi. Cambridge: University Press. p 191-201.

, Davey RA. 1984. Sigmoid conidial shape in aquatic fungi. Trans Br Mycol Soc 83:43-52.
Descals E. 1981. Morphology, distribution, and ecology of conidial fungi in freshwater habitats. In: Cole GC, Kendrick B, eds. Biology of conidial fungi. London: Academic Press. p 295-355.

Yuen TK, Hyde KD, Hodgkiss IJ. 1999. Interspecific interactions among tropical and subtropical freshwater fungi. Microb Ecol 37:257-262. 